\title{
The Art of Compromise of Indonesian Ahmadiyya Community in Yogyakarta
}

\author{
$1^{\text {st }}$ Mochamad Sodik* \\ Sociology Department \\ Faculty of Social Sciences and Humanities, \\ UIN Sunan Kalijaga \\ Yogyakarta, Indonesia \\ mochamad.sodik68@gmail.com
}

\author{
$2^{\text {nd }}$ B.J. Sujibto \\ Sociology Department \\ Faculty of Social Sciences and Humanities \\ UIN Sunan Kalijaga \\ Yogyakarta, Indonesia \\ bje_soejibto@yahoo.com
}

\begin{abstract}
This paper aims to elaborate the process of negotiation and compromise of Indonesian Ahmadiyya Community (JAI) in Yogyakarta among other religious groups, which mostly threaten and even commit violence against it, and toward society in general. This social process maintained by JAI is to make space for participation in order that its existence and teachings must be heard by public. By using qualitative approach, this study collected data from interview, documents, and media's coverage of JAI community in Yogyakarta. This study finds interesting strategies of negotiating, compromising, and adapting to social realm, which is called the art of compromise. Indeed, JAI is amenable to compromise with-instead of confronting and offendingvarious religious groups and institutions as well to build collaboration and partnership, like joining The Brotherhood Forum for Faithful Community (FPUB) instead of the Interreligious Harmony Forum (FKUB). Negotiation and compromise are two important factors played by JAI to maintain its existence, activities, and influences over public. Therefore, the art of compromise becomes more flexible approach for the JAI community to face pressure, discrimination, and even violence from other religious groups in Yoyakarta.
\end{abstract}

Keywords-Ahmadiyya, art of compromise, interfaith dialogue, Yogyakarta

\section{INTRODUCTION}

Living in a nation-state with irrevocably plural and multicultural background, the emergence of various social movements affiliated with other religious groups is reasonable and socially inevitable. The presence of the Ahmadiyya community, however, is a logical consequence of Indonesia's multicultural society and surprisingly it has had a much more obvious presence in Indonesia than the Shî‘a [1]. Since the 1920s, Ahmadiyya has been present in Indonesia with two different subgroups [2], namely Gerakan Ahmadiyah Indonesia (GAI) which is identified as Lahore branch of the Ahmadiyya and Jemaat Ahmadiyya Indonesia (JAI) from Qâdiyân branch of the Ahmadiyya. A Lahore branch of the Ahmadiyya came first to Yogyakarta in 1924 with a support from Muhammadiyah [3] and later a Qâdiyân branch of the Ahmadiyya reached the city after the independence of Indonesia in 1947. A Qâdiyân branch of the Ahmadiyya with abbreviation of JAI in Yogyakarta will be a focus of this paper.
Several years later in 1980, after Majelis Ulama Indonesia (MUI) officially declared heresy concerning the faith of Ahmadiyya, Ahmadiyya community started experiencing difficult position under persecution and violence. The MUI's declaration caused very serious impacts to the community which slowly but sure had been socially excluded. After the Post-Suharto era, dominant Islamic groups which were mostly anti-Ahmadiyya openly stood against it and committed violence in various ways so unavoidably that it likely started to become vulnerable to negotiating with other religious groups. The bitter experience having been continuously faced by the Ahmadiyya has made it moderate the ways how to preach the sermons, approach the surroundings and hold social negotiation and compromise as well.

In contemporary religious discourses, with wait-and-see policy which is potentially violated, social conflicts and violence involving JAI community in Indonesia have been rapidly growing in many regions throughout the country. As minority, the JAI's members are always at a disadvantage position. Certainly, acts of intolerance and violence against the JAI have been contested to become a national issue due to the escalation of violence which unfortunately killed dozens of members of JAI in many regions year after year. The massive violence which occurred in Cikeusik (Banten) [4], Kudus, (Central Java) [5], Manis Lor (Kuningan), Sampang (Madura), and East Lombok, (West Nusa Tenggara) - to mention some-are strong evidences to urgently be solved by government and other stakeholders in society in order to be able to live in harmony and peace amongst the multicultural Indonesia. Without a commitment to pay a lot of respect to minority rights either through structural powers or civil society, the idea of constructing Indonesia as an archipelago state with multicultural and pluralistic basis definitely will be more difficult to bring forward.

Meanwhile, a number of preliminary studies showed that conflict and violence in the name Ahmadiyya are not merely affected by external parties since internal Ahmadiyya community itself such as preachers and method of preaching were considered to be lacking any discretion and mutual understanding in the local context, for this case, of sociocultural background in Lombok's society. They seem to be exclusive and the teachings implacably oppose the beliefs of the local people of Lombok in general [6]. Therefore, a 
process of negotiating its position to fix into social and religious realm needs supportive environments represented by capable actors and long-range strategies. As a city of tolerance and other slogans named to the city of Yogyakarta, it seemingly becomes decisive factor to be more tolerant in facilitating various religious groups through the existence of public spheres which are supported by academia, society and social activism in the same time. Although JAI is still threatened by Indonesian Ulema Council (MUI) of Yogyakarta, the tension could be calmed down before escalating to open and massive violence.

Conducted in specific case of Yogyakarta, this research will figure out the JAI's social process of integration and compromise with other religious groups of which, in many cases outside the city, they try vehemently to get rid of the JAI. A qualitative approach is used to conduct this study, as Paul ten Have put it, to 'work up' one's research materials, to search for hidden meanings, nonobvious features, multiple interpretations, implied connotations, unheard voices [7]. In same way, qualitative research provides detailed description and analysis of the quality, or the substance, of the human experience [8] in order to deeply understand the topic through data in many forms required. The sample is determined by purposive techniques to obtain data in accordance with the purpose of research, including the actor, members of JAI in Yogyakarta and and intelectuals.

\section{LITERATURE REVIEW AND THEORETICAL PERSPECTIVE}

Studies on JAI in Yogyakarta are not so many like in the other regions of the country of which their religious groups have come into conflict with JAI's community. Institute of Southeast Asian Islam (ISAIs) under Sunan Kalijaga State Islamic University, Yogyakarta has recently conducted academic researches with several publications on Ahmadiyya such as Indonesian Ahmadiyya Community, Conflict, Nationality and Humanity (Cantrik Pustaka, 2018) and Ahmadiyya Caliphate and The Nation State (Cantrik Pustaka, 2019). These two books elaborate comprehensive topics ranging from social and cultural aspects, preaching activities, rituals, into system of caliphate [9] toward nationalism and nation state. The pilot projects have already contributed generously to enrich an academic discourse on Ahmadiyya and will inevitably lead to the issue of social misunderstandings on the community.

Specific research on JAI in Yogyakarta was conducted by Pratina Ikhtiyarini in 2012, an unpublished undergraduate thesis under the title The Existence of Indonesian Ahmadiyya Community (JAI) in Yogyakarta after Joint Ministerial Decree (SKB) of Three Ministries Year 2008 on Ahmadiyya. The decree whish was issued by the Ministry of Religion, the Attorney General Office and the Ministry of the Interior with the letter No. 3 Year 2008, No. KEP-033/A/JA/6/2008, and No. 199 Year 2008 was specifically targeted JAI, not GAI.

An interesting discussion aroused by Ikhtiyarini was about the attitude of the government of the Special Region of Yogyakarta (DIY), in this case Sri Sultan Hamengku Buwono $\mathrm{X}$ as governor, who did not impose the decree since the local government of Yogyakarta considered that DIY was quite conducive and safe, and the people were tolerant as well. According to the Sultan, the presence of Ahmadiyya in
Yogyakarta never caused problems. The local government's attitude was such a breath of fresh air for the Ahmadiyya community but at the same time there were still many elements of uncertainty for the community such as the absence of a clear policy with protection and security guarantee as well [10]. In the situation of uncertainty, therefore, the community had several strategies to face obstacle and pressure from the outside, so that they can maintain its existence profusely to join and take apart in many social activities and local communities in which its name was taken into consideration of the public.

Accordingly, negotiation and compromise are mostly conducted in both academic studies and practitioners favoring conflict moderation either in international stages of which the first one is generally shaped or in local contexts even in, for many cases developed in psychological perspectives, personal relationship. Social sciences especially those who are practitioners have taken advantages of the terms to practically measure how to reconcile the conflict in order to reach an agreement of all parties. Negotiation is laden with adjusting power of each party to be able to work collaboratively. As part of social group with high potential friction, Ahmadiyya community has been keenly shaped through negotiation and recognition.

I. William Zartman is one of the leading theorists from the Paul H. Nitze School of Advanced International Studies (SAIS) of Johns Hopkins University to be acknowledged when mentioning the term of negotiation in international context. Zartman states that, indeed, there is no authoritative theory of negotiation [11]. The negotiations turn from formula to details. It is sometimes preceded by a break in the negotiations to take stock and produce a reframing of the issues, or by an important concession that breaks the deadlock and opens the way to lesser, reciprocal concessions [12]. In dealing with a process of negotiation, as Zartman put it, there are closure situations which come in two types: negotiations that reach an agreement when Not Enough in comparison with original hopes and demands is still enough to make an agreement (Type I), and those that do not reach agreement because Enough was not enough (Type II). In the successful cases (Type I), the parties agree even though they do not reach their stated goals or bottom lines; a partial agreement was deemed sufficient to provide a positive outcome. In the unsuccessful cases (Type II), the parties settle important issues but even that amount of agreement is not sufficient to warrant a final positive outcome [13].

In doing so, many negotiations are mismatched, leading either to collapse or to mutual socialization in one direction or another. The socialization-on-the-job has to be dominated by one side/pattern or the other, lest it merely solidify and intensify the mismatching. Petitioned as minority and at the same time the mantle of Islamic orthodoxy publicly strongly denounced Ahmadi Muslims as heretics or misguided, Ahmadiyya community in Yogyakarta has had the pain of social rejection and experienced a deadlock. Zartman encloses endgame, as the closure phase of the negotiations, which occurs when the parties, after having taken stock of where they are in the process, come to the conclusion that an end - positive or negative - is in sight and they need to address their behavior to making it happen [14]. Facing both rejection and deadlock in many cases of Ahmadiyya community, endgame will probably be a trap since a party is 
challenged to managing another possible way to defend. The art of defense is the best resistance usually made by marginal groups [15].

Meanwhile, the mismatched negotiations will operate another step like compromise in measuring the power in order that one party is not to be excluded by another. Compromise is not state of losing; rather it could be a winwin solution in the middle of a quarrel that all parties know they cannot win. In some notion, compromise is another art of defense made by marginal groups like Ahmadiyya community. Ruysscher and Puttevils carefully looked at the art of compromise on Marine Insurance Institutions in Antwerp (1550-1570) as an important study to track it on the historical context. As part of social and economic process through interaction of many groups in society, compromise had been shaped to attain a specific goal of which each group has. In other respects, as Ruysscher and Puttevils put it, the compromise corroborated some practices should become standard rules, for example barratry, at the expense of nations that did not accept them [16].

Furthermore, Kenneth D. McRae sees how urgent a term of compromise is in multilingual societies which are more prone to conflict. The fate of Indonesian societies living with multiculturalism always demands a high commitment of harmonious and tolerant way of life in order to be able to openly manage conflict and violence. Method of conflict resolution by compromise, as McRae put it, is such "splitting the difference" in conjunction with other issues [17]. Splitting the difference is rather ambiguous but short-term strategy to be adopted by a party in which rational negotiation is closed and causes gridlock.

Similarly, finding a compromise on interpersonal relationship is an alternative way to solve problems. The art of compromise is a distinctive term conjured by John Mordecai Gottman after conducting intensive study on relationships in the context of marriage and the family for the past 40 years. There are three phases in the discussion of a marital issue. The first phase is "agenda-building," the objective of which is to get the issues out as they are viewed by each partner. The second phase is the "arguing phase," the goal of which is for partners to argue energetically for their points of view and for each partner to understand the areas of disagreement between them. The third phase is the "negotiation," the goal of which is compromise [18].

\section{RECONSIDERING THE ART OF COMPROMISE}

\section{A. FPUB instead of FKUB}

Negotiation is an art of considering the existence of living creature. It is always there to be a basic process of every minority group to count itself in many social organism as much as possible. Considering its self-efficacy and the role of limited-social interaction, Ahmadiyya community of Yogyakarta has taken advantage of democratic process through various social activism and local movement to succeed in specific situations. The presence of socialreligious organization like the Brotherhood Forum for Faithful Community (FPUB) made a space for Ahmadiyya to participate in various activities related to social and religious issues. In 1997, FPUB was initiated by some interfaith activists from Islam, Catholic, Christian, Hindu, Buddhist,
Khong $\mathrm{Hu} \mathrm{Cu}$, also those who were associated with local religions in Yogyakarta such as Kepercayaan terhadap Tuhan YME, Kejawen, Kawula Ngayogyakarta and Kerokhanian Sapto Dharmo.

FPUB which was established by 12 religious leaders from Yogyakarta organized a series of workshops involving religious communities, intellectuals and government officials as a response to 1998 riots in Jakarta [19]. It was formed as a common concern on multiple religious violence which flared up in anger throughout the country. The riots and massive violence at that time, for example the case of Situbondo, Tasikmalaya, Jatibening, Sanggau Ledo, Sampit, Poso, and Ambon, destroyed places of worship, schools, and other public facilities evoking suspicion of groups of tribes, religions, and races (SARA) [20].

An approach by JAI community of Yogyakarta to actively get involved in FPUB was the way how to pertain to the art of compromise since there was an intentional effort by Islamic orthodoxy to get rid of it from joining Interfaith Communication Forum (FKUB), an official interfaith forum founded by Minister of Religion. Although the was no space for JAI to take apart, it's best not to resist but preparing another way to accomplish an internal task was an alternative. As minority with intense resistance from another group, JAI it was used to adjust difficulties and always put its role at stake. Therefore, an approach to join social and religious group was such an operation in silence to made its role and existence still alive and become acknowledged.

As a branch of the official institution under ministry, stakeholders of the Inter-religious Harmony Forum (FKUB) have to always follow the rules and government policies and the same time voices of majority, that are addressed to stand against Ahmadiyya, become silent weapon to control them. FKUB has founded after government held an Interfaith Conference on November 30, 1969 at Gedung Dewan Pertimbangan Agung (DPA) Jakarta, which was attended by Muslim, Christian, Catholic, Hindu and Buddhist religious leaders. The planning to form a forum for religious harmony was then officially establish with the issuance of the joint decree (SKB) of the Ministry of Religious Affairs and the Ministry of Home Affairs Number 1 of 1969 [21]. In 2006 the government revised decree No. 1 of 1969 by issuing a joint decree number 8 and 9 of 2006.

A mandate of the formation of FKUB, of course, not solely for the regulation of building houses of worship, but the most important one is to create perpetual peace and harmony among religious believers in their respective regions [22]. In addition, FKUB's position is very crucial regarding to procedures to build places of worship. Local governments will not issue permit if there is no written recommendation letter from FKUB. The strategic position could be exploited politically by some actors to obstruct the construction of houses of worship. Catholic Church Yohanes Baptista in Parung has yet to obtain a building permit (IBM) because FKUB has refused to issue a recommendation letter [23].

\section{B. From One to All Parties}

JAI has experienced intimidations and social pressures, with leaving the room for formal negotiation and compromise to come to agreement by mutual concession are 
mostly closed. In the situation of gridlock, compromise to the situation is an ideal, not merely means surrender. JAI has finally arrived at compromise as a way to cope with the problems in the surrounding with the needs of the understanding that every conflict so pressure won't be always solved. As unwanted minority group, to compromise is to resistance at the same time, since JAI has to consider the power of relation which mostly oppresses it to be voiceless. In this context, compromise to everything is an approach made by JAI not to resist anyone/group but to make space for another, which likely defines itself as one to all parties. Living in the society with majority pressure and violence, a surrender to pressure is shameful but a must.

The basic approach of the art of compromise is a demand to always be steady and get ready to take opportunity anytime in attending social and public activates held by various religious groups in Yogyakarta. JAI had attended the FKUB's invitation several times. Invitations are usually formal and the activities are also official like governmental ceremonies. This way is used by JAI's members to possibly build a bridge between the religious groups and develop mutual understanding among them. On the other hand, the active involvement of JAI at FPUB is due to the wide opportunities given by interfaith activists to be able to perform in public. There was an opportunity to participate the Hamengku Buwono's loyal events and one of Ahamdi Muslims became a chair of the organizing committee. Such opportunity at the same time becomes an important medium to introduce the community (jemaat) to public.

The art of compromise is the art of defense itself organized by JAI to have social spaces as much as possible to perform and introduce its existence into public. JAI has realized that there is no enough power to bargain unless it must formulate the sporadic strategy in particularity. The art of compromise is all about approach and strategy to make sure that JAI must be stable, invulnerable and accessible to any parties and all situations as well. In fact, JAI is difficult to hold formal negotiation due to the power it has. Additionally, a pressure on JAI comes from all sides, especially from state which was issued a decree of Joint Ministerial Decree (SKB) of Three Ministries clarifying JAI as pervert and misguided group. The art of compromise, into the worst fact, is the art of giving in, the fact that the "compromise" here turned out to be close to the "lose" outcome. As a result, the JAI's "compromise" outcome was negotiated in the bargaining space between "win" and "lose." Each side would rather accept "lose" than have no agreement, yet each prefers its own "win" [24].

\section{CONCLUSION}

Social discrimination and violence against JAI have forced this group to play a more logical role by using all its strength to negotiate and compromise. The art of compromise is one of the keys to interacting with the environment by approaching as much as possible with various groups and other institutions in Yogyakarta. The choice of joining FPUB rather than of FKUB is an interesting fact which has been played by JAI of Yogyakarta so that its existence is still visible and recognized.

There are at least two important factors played by JAI as part of the art of defense, that is negotiation and compromise.
These two terms are very important for JAI to run the art of compromise more flexibly. So that JAI is able to adapt to many pressures and obstacles they face in Yoyakarta. In addition, the existence of Yogyakarta as a tolerant public space gives a longer breath for JAI community.

\section{ACKNOWLEDGMENT}

Thank you for the committees who awesomely organize The Annual International Conference on Social Sciences and Humanities (AICoSH), an initiative event with international caliber under my supervision as a Dean of Social Sciences and Humanities Faculty, UIN Sunan Kalijaga, Yogyakarta. Our special thanks also go to all colleagues at faculty for actively supporting each other in the name of academic works and all insights in reviewing this article. This article won't be finished without a support and communication with Ahmad Saifudin Mutaqi as a chairman of JAI in Yogyakarta.

\section{REFERENCES}

[1] H. L. Beck, "The Rupture of the Muhammadiyah with the Ahmadiyya," Bijdragen tot de Taal-, Land-en Volkenkunde, Vol. 161, No. 2/3 (2005), pp. 210-246.

[2] N. F. Fadhillah, "Towards Peaceful Islam: Jemaat Ahmadiyah Indonesia (JAI) as a New Social Movement," Masyarakat: Jurnal Sosiologi, Vol 22, No 1 (2017), pp. 35-52.

[3] D. R. Maulana, "Ahmadiyah Lahore di Yogyakarta 1924-1930: Suatu Pertumbuhan Awal di Pulau Jawa, ," unpublished undergraduate thesis, Faculty of Humanities, University of Indonesia, 2010. Pp. 39.

[4] L. N. Hakim, "Tindak Kekerasan Terhadap Jamaah Ahmadiyah Indonesia: Sebuah Kajian Psikologi Sosial," Aspirasi Vol. 2 No. 1, Juni 2011, pp. 17-30.

[5] M. Rosyid, "Resolusi Konflik Berlatar Agama: Studi Kasus Ahmadiyah di Kudus," Fikrah, Vol. I, No. 2, Juli-Desember 2013, pp. 387-412

[6] E. Budiwanti, "Jamaah Ahmadiyah dan Resistensi Sosial di Lombok," in Jurnal Harmoni, Vol. VI, No. 23, Juli-September 2007

[7] A. B. Marvasti, Qualitative Research in Sociology: An Introduction. London: SAGE Publications, 2004. pp. 7.

[8] P. T. Have, Understanding Qualitative Research and Ethnomethodology. London: SAGE Publications, 2004, pp. 5.

[9] A. A. Faiz, Khilafah Ahmadiyah dan Nation State. Yogyakarta: Cantrik Pustaka, 2019.

[10] P. Ikhtiyarini, "Eksistensi Jemaah Ahmadiyah Indonesia (JAI) di Yogyakarta Pasca SKB 3 Menteri Tahun 2008 tentang Ahmadiyah,” unpublished undergraduate thesis, Yogyakarta State University (UNY), 2010, pp. 99-100.

[11] I. W. Zartman [ed.], How Negotiations End, Negotiating Behavior in the Endgame. Cambridge: Cambridge University Press, 2019, pp. 287

[12] I. W. Zartman [ed.], ibid, pp. 3.

[13] I. W. Zartman [ed.], ibid, pp. 4.

[14] I. W. Zartman [ed.], ibid, pp. 3.

[15] M. Sodik, "Melawan Stigma Sesat Strategi Jai Menghadapi Takfiri," unpublished dissertation, Gadjah Mada University, 2015, pp. 39.

[16] D. D Ruysscher and J. Puttevils, "The Art of Compromise Legislative Deliberations on Marine Insurance Institutions in Antwerp (c. 1550-c. 1570)," Low Countries Historical Review, Volume 130-3 (2015), pp. 45 .

[17] K. D. McRae, Conflict and Compromise in Multilingual Societies: Belgium. Ontario: Wilfrid Laurier University Press, 1986, pp. 292.

[18] R. Bakeman and J. M. Gottman Observing Interaction: An Introduction to Sequential Analysis (Second edition). Cambridge: Cambridge University Press, 1997, pp. 189. 
[19] M. Sakai, E. Jurriëns, J. Zhang, and A. Thornton Z [ed.], Disaster Relief in the Asia Pacific: Agency and Resilience. London: Routledge, 2014, pp. 46.

[20] I. Subkhan, Hiruk Pikuk Wacana Pluralisme di Yogya. Yogyakarta: Kanisius, 2007, pp. 76-78.

[21] N. A. B. M. Yakub, "Peran Forum Kerukunan Umat Beragama (FKUB) Kota Batam dalam Mewujudkan Toleransi Umat Beragama," unpublished, IAIN Tulungagung, 2018, pp. 13-17.
[22] H. Mubarok, "Memperkuat Forum Kerukunan Umat Beragama (FKUB)," Dialog, Vol. 37, No.2, Des 2014, pp. 195.

[23] H. Mubarok, ibid, pp. 197.

[24] [23] I. W. Zartman and S. Touval (ed.), International Cooperation: The Extents and Limits of Multilateralism. Cambridge: Cambridge University Press, 2010, pp. 142. 